\title{
New Editor-in-Chief for the Journal of Business Ethics
}

We are proud to announce the appointment of Ed Freeman and Michelle Greenwood as the new editors of the Journal of Business Ethics. Together they will take on the role of editor-in-chief as of January 1st 2016.

Ed has been involved with the Journal of Business Ethics for many years. He has been a Guest Co-editor for three special issues, and he has published 15 papers in the Journal beginning in 1987. He has also co-edited special issues of Academy of Management Review (forthcoming), Academy of Management Journal, Journal of Management Studies, European Management Review, Brazilian Review of Business Management, Business and Society Review, and others. He has also co-edited monograph series for Oxford University Press (Ruffin Series), Cambridge University Press (Business, Value Creation and Society), and the Society for Business Ethics Ruffin Lectures Series). His latest book is Bridging the Values Gap with Ellen R. Auster (Barrett Koehler, 2015). He works in business ethics, stakeholder theory, and pragmatism. Ed is University Professor and Olsson Professor at the Darden School, University of Virginia.

Michelle has been involved with the Journal of Business Ethics since 2002 as an author, reviewer and Section Editor. She has also been associated with other major journals in the field including Business \& Society and Business Ethics Quarterly. Michelle's own research focuses on critical approaches to stakeholder theory, ethics and HRM, CSR and employment, corporate accountability, and publication ethics. She has guest co-edited special issues on Ethics and HRM for Journal of Business Ethics and on
Stakeholder Accounting for Journal of Management Studies. Together with Raza Mir and Hugh Willmott, she has recently edited the Routledge Companion to Philosophy in Organization Studies. Michelle is on the faculty at Monash University, Australia, where she teaches business ethics and CSR.

We are delighted that Ed and Michelle are ready to take over editorship from Alex Michalos and Deborah Poff. At the same time we are sad to see Alex and Deborah go. Together they founded the journal, which appeared for the first time in print in 1982, and which was one of the first peer reviewed journals in the field of business ethics. Almost 35 years later it has become the broadest business ethics journal in the field, the most cited one, and the only one in the field of business ethics listed in the FT45. We are very grateful to Alex and Deborah for this enormous achievement.

We are sure Ed and Michelle are the right candidates to safeguard Alex and Deborah's heritage and to lead the journal into the next era of its development. Please join us in thanking Alex and Deborah and in welcoming Ed and Michelle and wishing them all the best with the editorship of the journal.

Kindest regards,

Neil Olivier

Floor Oosting

Executive Editors

Springer Nature 